\title{
IS ABSOLUTE PITCH A SPECIAL ABILITY OR SOMETHING WE ALL HAVE? A REVIEW BASED ON GENETIC, NEUROSCIENTIFIC AND EXPERIMENTAL PSYCHOLOGICAL FINDINGS
}

\author{
Author: \\ Luca Kiss \\ Goldsmiths University of London \\ (London, United Kingdom) \\ Első szerző e-mail címe: \\ kissluca94@gmail.com
}

\section{Lectors:}

\author{
Prof. Falus András (Prof., PhD.) \\ Semmelweis Orvostudományi Egyetem \\ (Hungary) \\ Dr. Forrai Judit (DSc.) \\ Semmelweis Orvostudományi Egyetem \\ (Hungary)
}

Kiss, L. (2019): Is Absolute pitch a special ability or something we all have? A review based on genetic, neuroscientific and experimental psychological findings. Különleges Bánásmód, 5. (1). 69-75. DOI 10.18458/KB.2019.1.69

\begin{abstract}
Absolute pitch (AP), the ability to identify and produce musical pitches without a reference point, is extremely rare and is considered to be a special ability. Although research has focused on this topic for decades, there is no consensus about why AP only occurs in 1 out of 10.000 individuals and how it is acquired. Therefore, the present article aims to review and reconcile the previous findings in order to understand the potential contribution of training and genetics in AP acquisition. Based on experimental psychological and genetic findings, it is concluded that although some components of AP are implicit and exist in the general population, both early musical training and genetic factors are crucial for AP development. This conclusion is supported by neuroscientific findings that provide evidence for differences in activations in specific brain areas between AP possessors and non-possessors.
\end{abstract}

Keywords: absolute pitch, musical training, pitch memory, pitch labelling, relative pitch Disciplines: music, psychology

\begin{abstract}
Absztrakt
KÜLÖNLEGES KÉPESSÉG AZ ABSZOLÚT HALLÁS? ÁTTEKINTÉS GENETIKAI, NEUROLÓGIAI ÉS KÍSÉRLETI PSZICHOLÓGIAI TANULMÁNYOK ALAPJÁN.

Az abszolút hallás, vagy a zenei hangok referencia pont nélküli felismerése és produkálása, egy különleges és ritkán előforduló képesség. Annak ellenére, hogy a kutatások több mint egy évszázada foglalkoznak ezzel a témával, nincs egyértelmú válasz arra a kérdésre, hogy az abszolút hallás miért csak minden tízezredik emberben fordul elő és hogyan alakul ki. Ezért, a jelen tanulmány célja, hogy áttekintse a korábbi szakirodalmakat és megvizsgálja a zenei képzés és a genetika jelentőségét az abszolút hallás kifejlődésében. Az áttekintő vizsgálatunk a kísérleti pszichológiai és genetikai kutatások alapján azt a következtetést vonta le, hogy habár az abszolút hallás egyes komponensei az általános népességben is jelen vannak, a korai zenei képzés és genetikai tényezők döntő fontosságú az abszolút hallás kifejlődésében. Ezt a következtetést támasztják alá az idegtudományi kutatások eredményei is, amelyek különbségeket mutatnak az abszolút hallással rendelkező és nem rendelkező emberek között az egyes agyi területek aktiválásában.
\end{abstract}

Kulcsszavak: abszolút hallás, zenei képzés, hang emlékezet, hang megnevezés, relatív hallás Diszciplina: zene, pszichológia,

Research on absolute pitch (AP), has grown significantly over the last decade (Levitin \& Rogers, 2005) and it refers to the ability to identify (i.e., pitch labelling) or produce (i.e., pitch memory) a specific pitch without any external reference point (hence the term 'absolute'; Baggaley, 1974). It only occurs in 1 out of 10.000 individuals (Profita \& Bidder, 1988; Ward, 1999) and is in interest of geneticists, neuroscientists and experimental psychologists (Zatorre, 2003). There are two rea- 
sons for that: Firstly, AP provides a way to understand how specialised abilities are linked to brain functions, and secondly, AP is a great example of how genetic factors and environmental input during development influence cognitive ability (Zatorre, 2003). Despite the large interest in this area, AP is still regarded as a mysterious talent, because of the controversial findings on its defining skills and mechanisms (Levitin, 1994). Some theories suggest that AP can be learned through early childhood musical training, while others assume that AP depends only on genetic factors and is independent from musical experience (Boss, 2004). The present article aims to disentangle this controversy by reviewing the existing literature and showing that both genetics and early musical training are crucial for AP acquisition. This review will first explore the implicit components of absolute pitch, before focusing on the importance of early musical training. Then, it will look at the contribution of genetic factors and the specific brain areas assotiated with AP.

\section{Implicit components of absolute pitch}

Even though eliciting AP is rare, most people have an implicit form of AP (Deutsch, 2013). According to the two-component model, both absolute pitch memory and pitch labelling are necessary for possessing AP (Levitin, 1994). A growing number of empirical studies suggest that pitch memory, the ability to hold stable information of pitch in long-term memory, is an ability most people have (Zatorre, 2003). For example, people can easily identify a musical note as coming from a piano rather than a guitar and they can remember and produce a pitch from their favourite pop song (Zatorre, 2003; Levitin, 1994). Based on this idea, Levitin (1994) proposed that AP is not a mysterious ability, but only a small increase in memory capacities that are nevertheless unexceptional in the general population. He hypothesised that repeated exposure creates memory representations of the songs with the correct pitches that is later accessible to the participants. There were 46 participants in the study with and without music background and $2 \mathrm{AP}$ possessors. Participants listened to pop and rock songs that only exist in one key, thus providing one exact pitch. They were asked to identify pitches in the songs and recall the accurate pitches in a production task. Importantly, Levitin (1994) found that $40 \%$ of the participants could perform without error on at least one trial and that the errors made by participants were within 1 and 2 semitones of the correct pitch and not evenly randomly distributed. Therefore, this provides evidence that absolute pitch memory exists in the general population and is a stable memory representation.

Other evidence for an implicit AP comes from Deutsch (1992), who used the Tritone Paradox based on the pitch class circle to test whether people hear an ascending or descending pattern. The pitch class circle consists of the 12 notes from the Western musical scale (1 octave divided into 12 semitone steps), in which the note names are repeated across octaves (see Figure 1) (Deutsch, 1992). The Tritone Paradox consists of two successive musical notes on the pitch class circle that are connected by half on octave (a tritone). Although the note names are clearly defined on the circle, the octave they are in is ambiguous (whether it is a middle $\mathrm{C}$, a $\mathrm{C}$ an octave above or below), consequently there is no correct answer whether a pattern is ascending or descending. Surprisingly, Deutsch (1992) found that when a tone pair was played (i.e., D and $\mathrm{G \#}$ ), some listeners heard an ascending, while others heard a descending pattern. Then, when another tone pair was played (i.e., F\# and $\mathrm{C}$ ), the first group heard a descending pattern and the second group heard an ascending pattern. Importantly, the pitch classes were perceptually systematic with relevance to their height for each participant. This means that tones on one part of the pitch class circle were heard as higher, and on the other part as lower. Based on these findings, Deutsch (2013) concluded that average people judge the relative heights of tones' pitch classes when they refer to them, which highlights the use of pitch memory and an implicit form of AP.

Research has also explored whether pitch labelling, the other component of AP, is implicit. As Schellenberg, Iverson and McKinnon (1999) highlighted, ordinary people are able to label pitches to some degree, but rather than identifying a musical tone by name (e.g., C, F\#, etc.), non-AP possessors simply use 'ad hoc' labels tied to the lyrics. For example, most people familiar with the song 'Hotel California' will sing the right note for the word 'hotel', but only AP possessors can link 'hotel' to the note G (Levitin \& Rogers, 2005). Thus, although there is empirical evidence for an implicit form of AP in the general population, verbally labelling isolated notes is the one component that makes AP possessors special. 
Figure 1. The pitch class circle representing the 12 semitone steps in an octave in the Western musical scale (Deutsch, 1992)

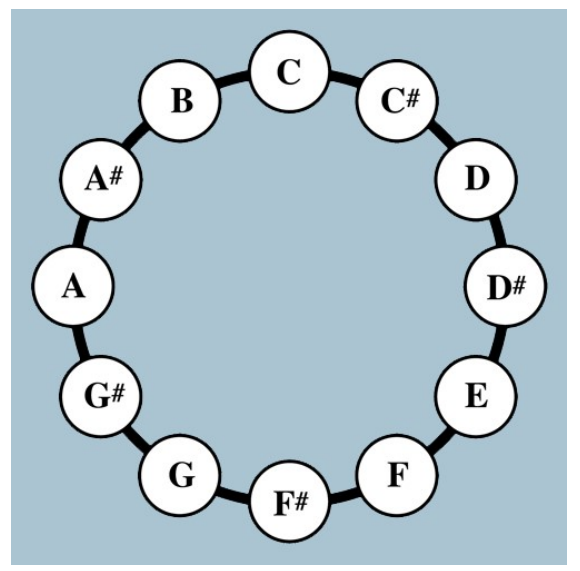

\section{Sensitive onset period}

How the ability of pitch labelling could be attained is, however, still unclear. Many hypotheses have been proposed to explain AP development, some arguing that it is possible to learn AP during a sensitive learning period, while others arguing that its development is genetic (Deutsch, 2013). Clearly, musical training is essential for verbally labelling pitches (Zatorre, 2003), but research has shown that it must happen early in life (up to 9-12 years of age; Miyazaki, 1988; Baharloo, Johnston, Service, Gitschier, \& Freimer, 1998). Nonetheless, even though the prevalence for AP is higher amongst people who started music education before the age of 6 (Baharloo et al., 1998; Gregersen, Kowalsky, Kohm, \& Marvin, 1999), not all of them develop AP (Zatorre, 2003; Deutsch, 2013). It might partially depend on the type of training they receive, because the majority of training techniques focus on relative pitch (RP), the ability to produce or recognise intervals or relations with other pitches (Levitin \& Rogers, 2005), rather than teaching the specific pitches themselves (Zatorre, 2003). Furthermore, the type of instrument(s) one learns might also influence AP development. Specifically, some instruments do not have fixed-pitches (e.g., violin) and if one plays more than one instrument, those might not be tuned for the same standard which could hinder AP acquisition (Zatorre, 2003).

A study by Saffran and Griepentrog (2001) showed that infants indeed prefer to use AP cues over RP cues, but there is a shift to prioritise RP cues in adulthood as a consequence of the mentioned factors (e.g., training technique, instruments played). Saffran and Griepentrog (2001) tested the use of AP and RP cues in a statistical learning task in 20 8-month-olds and 120 adults during which they learned tone sequences. Interestingly, they found a shift between the use of pitch cues in in- fants and adults. While infants relied heavily on AP cues and could not perform successfully on the task based on RP patterns, adults showed the opposite results and could only perform above chance when they relied on RP cues. The researchers therefore argued that this shift occurs because of RP information being more useful for music and speech processing (Saffran \& Griepentrog; 2001). Nevertheless, these results only suggest that people prioritise different pitch information at different ages and cannot conclude that only one type of information is used by infants and adults. Furthermore, the stimuli used in this study were unsegmented, unmusical tone sequences, and more complex musical stimuli should also be tested in the future.

Further evidence for a sensitive onset period was found by Deutsch, Henthorn, Marvin and Xu (2006), who compared the presence of AP between 88 Chinese and 115 American music students. They used a large-scale study during which participants were asked to identify 36 music notes in writing either by letter name (e.g., D, C\#, etc.) or by solfeggio name (do, do-sharp, re, etc.). The letter and sofeggio names indicated 'moveable-do training' and 'fixed-do training', respectively. Importantly, Deutsch et al. (2006) found that participants who started training earlier had higher probability of attaining AP and the prevalence of AP was found to be significantly higher amongst Chinese than American students. In particular, 60\% of Asian students who started training before the age of five had AP compared to $17 \%$ of Western students. Moreover, up to the onset age of 9 years, moveable-do participants scored twice as high on the AP test than fixed-do participants. Interestingly, moveable-do learning techniques are more common in China, where the prevalence of AP was also found to be much higher, which might 
suggest a correlation between moveable-do learning and AP (Deutsch et al., 2006).

In light of these findings, it is possible that more people would establish AP given the right and early training but training itself cannot explain why children have AP despite hearing out-of-tune instruments and singing (Zatorre, 2003). It also cannot explain why some people who receive AP specialised training can never become AP possessors (Zatorre, 2003). Moreover, many AP possessors do not remember acquiring this ability in their lives and report that it happened naturally to them, which indicates that there must be other contributors apart from training (Zatorre, 2003). A feasible reason for the unusual distribution of AP in the population could be that there are some underlying genetic factors (Levitin \& Rogers, 2005).

\section{Genetic factors}

Many previous studies have investigated the genetic components of AP and showed an association between siblings, first-degree relatives and twins, even when early musical training and other environmental factors are accounted for (Baharloo, Service, Risch, Gitschier, \& Freimer, 2000; Baharloo et al., 1998; Gregersen, 1998; Gregerson et al., 1999; Profita \& Bidder, 1988). For example, Baharloo et al. (1998) conducted a survey study with 600 musicians and reported that individuals possessing AP were four times more likely to have a relative with AP than non-AP possessors. Nonetheless, early musical training was still important: almost all AP possessors started training before the age of 6 (Baharloo et al., 1998). Thus, this indicates an interaction between genetics and a critical learning period in childhood, during which some individuals are more receptive to improved pitch perception than others (Baharloo et al., 1998). One limitation of this study is, however, that the survey was a self-report questionnaire and some participants might have judged the AP ability of themselves and their family members more critically than others (Baharloo et al., 1998).

Another survey study was performed by Gregersen et al. (2001) to test whether AP is differentially distributed in the population, with Asian people having a higher prevalence rate than Caucasian people. Similarly to the hypothesis, the researchers found that out of the 1067 music student participants in the United States, $47.5 \%$ of Asian students reported having AP compared to $9 \%$ of Caucasian students. The high AP prevalence amongst Asian students was found to be unrelated to sociocultural variables, because it was also reported in Americans with an Asian descent. It was also independent of speaking a tonal language as not all Asian languages involved in the experiment are tonal (e.g., Chinese, Korean, Japanese; Zatorre, 2003; Baharloo et al., 2001). Interestingly, the higher AP rate in Asian ethnicities remained even after controlling for the early exposure to music and moveable-do musical training of Asian children. Based on these findings the researchers concluded that there is a genetic factor in AP development (Baharloo et al., 2001; Gregersen et al., 2001; Zatorre, 2003).

A few years later, Henthorn and Deutsch (2006) reanalysed the data obtained by Gregersen et al. (2001) and found that there was no significant difference in AP prevalence between East Asian and Caucasian participants when taking only those participants who spent their early childhood in North America into account. This prevalence was still significantly higher for individuals who spent their early childhood in East Asia rather than North America, thus again highlighting the importance of environmental factors (Henthorn \& Deutsch, 2006).

Nonetheless, the unusual distribution of AP scores in the population made researchers conclude that there are indeed genetic contributing factors to this trait (Athos et al., 2007; Bermudez \& Zatorre, 2009; Deutsch, Dooley, Henthorn, \& Head, 2009). Instead of a continuous distribution, the scores attained on AP tests were similar to a bimodal distribution, with some people performing with very high accuracy, some near the generally accepted AP criteria and some at chance (Athos et al., 2007; Bermudez \& Zatorre, 2009; Deutsch, Dooley, Henthorn, \& Head, 2009). Considering that most human traits have a normal distribution with extraordinary individuals on the high end (Drayna, 2007), the distribution of AP scores is indeed unusual, indicating a genetic basis (Deutsch, 2013).

Yet, to justify the idea of a genetic factor, there should be a gene that is responsible for the AP trait (Deutsch, 2013). To locate parts of the human genome that could be related to an APpredisposing gene, Theusch, Basu and Gitschier (2009) performed a whole-genome linkage analysis on 69 families. They found that the most powerful proof for a connection was on the 8th chromosome in multiplex AP families with European ancestry and a chromosome 7 peak was also apparent across 19 multiplex AP families with East Asian ancestry (though this peak did not reach significance level). Therefore, as Deutsch et al. (2013) later suggested, although these results provide good preliminary evidence for a genetic basis of $\mathrm{AP}$, the discovery of a specific $\mathrm{AP}$ gene requires future research. 


\section{Brain areas linked to absolute pitch}

Research has also focused on the neurological underpinnings of AP to understand the genetic and enviromental contribution to its acquisition as well as the differences in brain mechanisms between AP possessors and non-possessors. Structural and functional neuroimaging studies found that some networks of cortical areas are uniquely structured in AP possessors that reflect both innate and environmental influences during the critical period (e.g., Bermudez \& Zatorre, 2009; Zatorre et al., 1998; Oechslin, Meyer, \& Jancke, 2009; Schulze, Gaab, \& Schlaug, 2009; Wilson, Lusher, Wan, Dudgeon, \& Reutens, 2008). Specifically, Zatorre et al. (1998) conducted three experiments to explore which brain areas are related to AP. In the first experiment, they found that the planum temporale (PT), an anatomical marker of auditory association area (Loui, Li, Hohmann, \& Schlaug, 2010), was more asymmetrical on the left part in AP possessors than controls in a pitchnaming task, while there was no significant difference on the right side (Zatorre et al., 1998). This exaggerated asymmetry on the left was related to less errors in identifying pitches and to auditory processing, meaning that the left hemisphere of AP possessors is biased towards processing pitch information (Zatorre et al., 1998; Loui et al., 2010). Keenan et al. (2001) confirmed the increased leftward PT asymmetry, though in their study it resulted from a right PT smaller than average.

In the second experiment with positron emission topography (PET), Zatorre et al. (1998) measured cerebral blood flow and found that individuals with AP showed activations in the left posterior dorsolateral frontal cortex when they named single notes, whereas RP possessors only showed that activation when naming intervals (whether minor or major). Interestingly, the posterior dorsolateral area of the frontal cortex is also associated with learning conditional associations (Zatorre et al., 1998), proposing that the activation might only happen in AP possessors, because only they can label individual tones readily (Zatorre, 2003). This also points out the importance of enviromental factors and receiving the right training method. This finding is further supported by Ohnishi et al. (2001), who also observed an increased activation of the left posterior dorsolateral frontal cortex during a music listening task in people who scored high on AP.

Interestingly, another finding by Zatorre (1998) was that there was no activity in the right inferior frontal cortex of AP possessors compared to controls in an interval-judgment task, indicating that there is no need to access working memory for AP possessors in such tasks and they can rely on their long-term memory and categorical representation of tones instead. Schulze et al. (2009) supported this conclusion and conducted a pitch memory experiment with functional MRI. Similarly to Zatorre et al. (1998), Schulze et al. (2009) also found that AP possessors have a categorical representation of tones, because there was an activation of the left superior temporal sulcus that is involved in the categorisation of tasks. Additionally, Schulze et al. (2009) have shown an increased activation of the right superior parietal lobule and intraparietal sulcus in non-AP possessors, which indicates the use of working memory and the use of a multimodal encoding strategy (i.e., imagining notes on a scale) for recalling pitch information. This therefore provides additional support for the view that nonAP possessors require conscious efforts to identify pitches compared to AP possessors who can label pitches automatically.

\section{Future directions}

Although these neuroscientific findings help better understand the underlying mechanisms of AP, the cause and effect relationship is still unknown (Levitin \& Rogers, 2005). Thus, in the future, research should investigate whether the neurological differences between AP possessors and non-possessors cause or affect $\mathrm{AP}$ and the joint contributions of both genetic and environmental factors. In addition, future studies should explore the idea of a sensitive learning period and the necessary conditions during that period for successful AP acquisition.

\section{Conclusions}

In summary, this review explored the existing literature on AP with relevance to its acquisition. It showed that even though most people have some implicit aspects of AP, such as memory for pitch, having AP is a special ability. Based on relevant research, it is suggested that AP acquisition depends on both genetic and environmental factors, such as receptivity to pitch perception and training techniques, which could explain its rarity and unusual distribution in the general population.

\section{REFERENCES}

Athos, E. A., Levinson, B., Kistler, A., Zemansky, J., Bostrom, A., Freimer, N., \& Gitschier, J. (2007). Dichotomy and perceptual distortions in absolute pitch ability. Proceedings of the National Academy of Sciences of the U.S.A, 104, 1479514800.

Baggaley, J. (1974). Measurement of absolute pitch. Psychology of Music, 2(2), 11-17. 
Baharloo, S., Johnston, P., Service, S., Gitschier, J., \& Freimer, N. (1998). Absolute pitch: an approach for identification of genetic and nongenetic components. American Journal of Human Genetics, 62, 224-231.

Baharloo, S., Service, S., Risch, N., Gitschier, J. \& Freimer, N. (2000). Familial aggregation of absolute pitch. American Journal of Human Genetics, 67, 755-758.

Bermudez, P., \& Zatorre, R. J. (2009). The absolute pitch mind continues to reveal itself. Journal of Biology, 8, 75. doi:10.1186/jbiol171

Boss, D. A. (2004). A nonmusical paradigm for identifying absolute pitch possessors. The Journal of the Acoustical Society of America, 116(3). 17931799.

Deutsch, D. (1992). Paradoxes of musical pitch. Scientific American, 267, 88-95.

Deutsch D. (2013). Absolute pitch, in The Psychology of Music, D. Deutsch, (Ed.), pp. 141-182. San Diego, CA: Academic Press.

Deutsch, D., Henthorn, T., Marvin, E., \& Xu H. S. (2006). Absolute pitch among American and Chinese conservatory students: Prevalence differences, and evidence for a speech-related critical period. Journal of the Acoustical Society of America, 119. 719-722.

Deutsch, D., Dooley, K., Henthorn, T., \& Head, B. (2009). Absolute pitch among students in an American music conservatory: association with tone language fluency. Journal of the Acoustical Society of America, 125, 2398-2403

Drayna, D. T. (2007). Absolute pitch: A special group of ears. Proceedings of the National Academy of Sciences, U.S.A, 104, 14549-14550.

Gregersen, P. K. (1998). Instant recognition: the genetics of pitch perception. American Journal of Human Genetics, 62, 221-223. doi: 10.1086/301734

Gregersen, P. K., Kowalsky, E., Kohn, N., \& Marvin, E. W. (1999). Absolute pitch: prevalence, ethnic variation, and estimation of the genetic component. American Journal of Human Genetics, 65, 911-913.

Gregersen, P. K., Kowalsky, E., Kohn, N., \& Marvin, E. W. (2001). Early childhood music education and predisposition to absolute pitch: Teasing apart genes and environment. American Journal of Medical Genetics, 98, 280-282.

Imaizumi, K., Priebe, N. J., Crum, P. A. C., Bedenbaugh, P. H., Cheung, S. W., \& Schreiner, C. E. (2004). Modular functional organization of cat anterior auditory field. Journal of Neurophysiology, 92, 444-457.

Keenan, J. P., Thangaraj, V., Halpern, A. R., \& Schlaug, G. (2001). Absolute pitch and planum temporale. NeuroImage, 14, 1402-1408.

Levitin, D. (1994). Absolute memory for musical pitch: Evidence from the production of learned melodies. Perception \& Psychophysics, 56, 414-423.

Levitin, D. J. \& Rogers, S. E. (2005). Absolute pitch: perception, coding, and controversies. Trends in Cognitive Sciences, 9(1), 26-33. doi:10.1016/j.tics.2004.11.007.

Loui, P., Li, H., Hohmann, A., \& Schlaug, G. (2011). Enhanced cortical connectivity in absolute pitch musicians: a model for local hyperconnectivity. Journal of Cognitive Neuroscience, 23, 1015-1026.

Miyazaki, K. (1988). Musical pitch identification by absolute pitch possessors. Perception and Psychophysics, 44, 501-512.

Oechslin, M. S., Meyer, M., \& Jancke, L. (2009). Absolute pitch-Functional evidence of speech-relevant auditory acuity. Cerebral Cortex, 20, 447-455.

Ohnishi, T., Matsuda, H., Asada, T., Atuga, M., Hirakata, M., Nishikawa, M., Katoh, A., \& Imabayashi, E. (2001). Functional anatomy of musical perception in musicians. Cerebral Cortex, 11, 754-760.

Profita, J., \& Bidder, T. G. (1988). Perfect pitch. American Journal of Medical Genetics, 29, 763-771.

Saffran, J. R., \& Griepentrog, G. J. (2001). Absolute pitch in infant auditory learning: Evidence for developmental reorganization. Developmental Psychology, 37(1), 74-85.

Schellenberg, E. G., Iverson, P., \& McKinnon, M. (1999). Name that tune: Identifying popular recordings from brief excerpts. Psychonomic Bulletin \& Review, 6(4), 641-646.

Schulze, K., Gaab, N., \& Schlaug, G. (2009). Perceiving pitch absolutely: Comparing absolute and relative pitch possessors in a pitch memory task. BMC Neuroscience, 10, 106 - 119. doi:10.1186/1471-2202-10-106

Theusch, E., Basu, A., \& Gitschier, J. (2009). Genome-wide study of families with absolute pitch reveals linkage to 8q24.21 and locus heterogeneity. American Journal of Human Genetics, 85, 112-119.

Ward, W.D. (1999) Absolute pitch. In the Psychology of Music (Deutsch, D. Ed.), pp. 265-298. Academic Press.

Wilson, S. J., Lusher, D., Wan, C. Y., Dudgeon, P., \& Reutens, D. C. (2008). The neurocognitive components of pitch processing: Insights from absolute pitch. Cerebral Cortex, 19, 724-732.

Zatorre, R. J. (2003). Absolute pitch: A model for understanding the influence of genes and development on neural and cognitive function. Nature Neuroscience, 6, 692-695. 
Zatorre, R. J., Perry, D. W., Beckett, C. A., Westbury, C. F., \& Evans, A. C. (1998). Functional anatomy of musical processing in listeners with absolute and relative pitch. Proceedings of the National Academy of Sciences of the U.S.A., 95, 3172-3177. 